\title{
BILINGUAL BARBARIANS IN LA BODA AND ESCUELA: THE ADOLESCENCE AND ASSIMILATION OF TWO MIGRANT SISTERS
}

\author{
Alexandra Jorgevna Sanchez ${ }^{1}$ \\ ${ }^{1}$ Katholieke Universiteit Leuven, Leuven, Flandres, Belgium
}

\begin{abstract}
In this article, I argue that Hannah Weyer's documentaries $L a$ boda (2000) and Escuela (2002) use the metaphor of teen angst to explore how receiving countries tend to equate the process of successful immigration with that of reaching adulthood. With her unobtrusive camera work, Weyer invites the viewer to become aware of the disturbing parallel between the coming-of-age of the Luis sisters and the assimilation process imposed on them, as second-generation immigrants in the US. Navigating through different stages of adolescence, Liliana and Elizabeth struggle as much with the transition from children to grown-ups as they do with the unspoken cultural expectation that in order to climb the socio-economic ladder they are to leave their Mexican roots behind. Real-life examples of the "immigrant paradox" (Coll \& Marks; Markides \& Coreil; Portes \& Zhou; Wirth), "the second generation revolt" (Gans) or "the second generation decline" (Perlmann \& Waldinger), the sisters do not seem to continue the "straightline assimilation" that was initiated by their parents ( $c f$. Park \& Burgess; Warner \& Srole). Based on the zealous assumption that each generation that issues from immigration will go through a gradually smoother incorporation into mainstream society, the straight-line assimilation theory predicts upward mobility for each generation in matters of education and employment thanks to increasing residential concentration and intermarriage patterns, and decreasing ethnic distinctiveness in language use (Waters et al.). However, as Elizabeth and Liliana go through financial, legal, and educational turmoil, they do not simply poke holes in this overly enthusiastic theory. They demonstrate that with the way the American schooling and social security systems are currently designed, their demographic was always set up to fail anyway (cf. Berry; Berry et al.; Marks et al.).
\end{abstract}

Keywords: Migration; Documentary; Segmented Assimilation; Barbarian; Mexican Immigration 


\title{
OS BÁRBAROS BILÍNGUES EM LA BODA E ESCUELA: A ADOLESCÊNCIA E ASSIMILAÇÃO DE DUAS IRMÃS MIGRANTES
}

\begin{abstract}
Resumo: Nesse artigo, eu argumento que os documentários de Hannah Weyer, La boda (2000) e Escuela (2002), usam a metáfora da angústia adolescente para explorar como países receptivos tendem a igualar o processo bem sucedido de imigração com o de chegada à vida adulta. Com seu discreto trabalho de câmera, Weyer convida o espectador a tomar consciência do perturbador paralelismo entre a maioridade das irmãs Luis e o processo de assimilação imposto a elas, como segunda geração de imigrantes nos EUA. Percorrendo diferentes estágios da adolescência, Liliana e Elizabeth lutam tanto com a transição de crianças para adultas quanto com silenciosa expectativa cultural de que, por causa da necessidade de subir na escada socioeconômica, elas devem deixar sua descendência mexicana para trás. Exemplos reais do "paradoxo do imigrante" (Coll \& Marks; Markides \& Coreil; Portes \& Zhou; Wirth), "a revolta da segunda geração" (Gans) ou "o declínio da segunda geração" (Perlmann \& Waldinger), as irmãs não parecem continuar a "assimilação direta" que foi iniciada por seus pais ( $c f$. Park \& Burgess; Warner \& Srole). Baseada na assunção de que cada geração resultante da imigração passará por um processo gradual de incorporação à sociedade geral, a teoria da assimilação direta prediz uma mobilidade ascendente para cada geração no que diz respeito à educação e ao emprego por causa da crescente concentração residencial e os padrões de casamento entre diferentes raças, e da diminuição da distinção étnica no uso da língua (Waters et al.). Todavia como Elizabeth e Liliana passam por turbulências financeiras, sociais e educacionais, elas não apenas demonstram falhas nessa teoria excessivamente entusiástica. Elas demonstram que do jeito que os sistemas de educação escolar e seguridade social americanos estão atualmente projetados, sua demografia foi sempre configurada para falhar de qualquer maneira ( $c f$. Berry; Berry et al.; Marks et al.).
\end{abstract}

Palavras-chave: Migração; Documentário; Assimilação Segmentada; Bárbaro; Imigração Mexicana

In La boda (2000) and Escuela (2002), documentary maker Hannah Weyer attempts to disengage the notion of migration from the concept of illegality. In order to do so, she follows the Mexican-American Luis family as they migrate back and forth 
between their home in Texas and the labor camps in California, in search of seasonal fieldwork. As it turns out, Weyer's migratory protagonists - father Eliazar, mother Juanita, and their 8 children - are not illegal aliens, but US citizens who have been forced to lead a transient lifestyle for a lack of other reliable job opportunities. In La boda (Weyer, "La Boda"), the focus is on Eliazar and Juanita's 22-year-old daughter Elizabeth and her upcoming wedding to Artemio, a Mexican bracero she met while working in the fields. The first of her siblings to graduate from high school, Elizabeth is nevertheless quite down-to-earth about her perspectives, needs, and wishes: all she wants is to get married, find decent housing, and make sure Artemio's papers for legal residence come through. Her little sister Liliana takes over in Escuela (Weyer, "Escuela") and follows in Elizabeth's footsteps to become the second Luis sibling to study beyond $8^{\text {th }}$ grade. For the duration of an entire schoolyear, Weyer shadows buoyant and cheeky Liliana as she makes her debuts as a high school freshman. Indeed, because her migrant family follows the harvests across state borders and moves several times a year, Liliana has to enter two different schools and experience the novelty and anxiety of being "the new kid" twice over.

In this article, I argue that both documentaries use the metaphor of teen angst to explore how receiving countries tend to equate the process of successful immigration with that of reaching adulthood. With her unobtrusive camera work, Weyer invites the viewer to become aware of the disturbing parallel between the coming-of-age of the Luis sisters and the assimilation process imposed on them, as second-generation immigrants in the US. Navigating through different stages of adolescence, Liliana and Elizabeth struggle as much with the transition from childhood to adulthood as they do with the unspoken cultural expectation that in order to climb the socioeconomic ladder they have to leave their Mexican roots behind. Real-life examples of the "immigrant paradox" (Coll \& Marks; Markides, Coreil; Portes, Zhou; Wirth) "the second generation revolt" (Gans) or "the second generation decline" (Perlmann \& 
Waldinger), the sisters do not seem to continue the "straight-line assimilation" that was initiated by their parents ( $c f$. Park \& Burgess; Warner \& Srole). Based on the assumption that each generation that issues from immigration will go through a gradually smoother incorporation into mainstream society, the straight-line assimilation theory predicts upward mobility for each generation in matters of education and employment thanks to increasing residential concentration and intermarriage patterns, and decreasing ethnic distinctiveness in language use (Waters et al.). However, as Elizabeth and Liliana go through financial, legal, and educational turmoil, they do not simply poke holes in this overly enthusiastic theory. They demonstrate that given the way the American schooling and social security systems are currently designed, their demographic was always set up to fail anyway (Marks et al.)

Weyer's depiction of the Luis sisters does not point fingers at their attachment to their parents' homeland or the Mexican twang of their English speech. On the contrary, the camera seems to celebrate Elizabeth and Liliana's biculturalism and bilingualism by capturing the curiously refreshing and unique ways in which they respond to situations where their Mexican and American worlds collide. That being said, as much as Escuela and La boda mitigate the demonizing accounts of barbaric Hispanics that have become part and parcel of the American collective unconscious ( $c f$. Huntington, Who Are We?), they also step away from romanticizing the counterhegemonic notion that juggling two languages and two cultures necessarily results in hybridity and mestizaje, an idea promoted by the likes of Gloria Anzaldúa, Guillermo GómezPeña, and so on (Moreman, Performativity and the Latina/o-White Hybrid Identity; Valdivia; Vila).

\section{Monolingualism and Assimilation}

La boda was first broadcast on PBS (Public Broadcasting Service) in June 2000 as part of the award-winning public television 
series POV (point of view) - America's longest-running showcase of independent documentaries. Escuela aired in August 2002 and is presented on the POV website as a "follow-up" to La boda: a "compassionate portrait" of yet another member of the Luis family (Escuela | POV | PBS). A documentary tandem, La boda and Escuela play Elizabeth and Liliana's sisterly characters off of each other and comment - directly and indirectly - on their lives, highs and lows, dreams and fears. If Elizabeth's marriage functions as the catalyst and climax of La boda, then Escuela jumps on La boda's bandwagon and builds on its momentum. Escuela adds a new dimension to Elizabeth's life journey by way of Liliana's filmic narrative, which serves the purpose of both a sequel and a prequel to the older sister's nuptials.

Essentially a frenzied build-up to Elizabeth and Artemio's wedding ceremony, La boda places Elizabeth firmly at the heart of the plot. The other members of the Luis family play second fiddle. Weyer appears to cast them in the role of Elizabeth's unsuspecting Greek chorus, interviewed and highlighted only to enhance the bride's actions, words, cogitations. In Escuela, however, Liliana does not always take center stage. Her cumbersome high school experience echoes Elizabeth's, who regularly makes guest appearances in - what is supposed to be - Lili's film and thus punctuates her little sister's teenage existence with dramatic glimpses of what her future might hold. The mood in Escuela is therefore more somber than in La boda, as Elizabeth's outdrawn struggle in Escuela to legalize her husband's status and find decent housing and work for both of them underpins Liliana's day-to-day reality and foreshadows her own bleak prospects.

La boda begins by setting a distinctly ambiguous, neitherhere-nor-there tone that is carried through in both films. For an uncomfortably long while, Weyer focuses only the actions of her cast, not on their words. For as long as possible, she delays the moment her characters speak and give away their identities, implying from the beginning that language and identity will be inextricably intertwined in her storyworld - another theme runs 
through in both documentaries. Having disarmed her audience in these first few moments by withholding a clear plotline, or focal character or verbal commentary, Weyer then unleashes a sensory overload of sounds and images meant to confuse and disorientate her viewers, tempting them to look for contextual clues in this sea of conflicting signals. The first images of La boda are almost voyeuristic (00:02:20-00:05:50). As the captions announce it is $4.30 \mathrm{am}$ in a migrant labor camp in Shafter, California, the camera mimics the shaky movements of a Peeping Tom lurking from behind the bushes, eyeing a one-story house that seems to glow in the dark, its indoor lights beaming through the windows. Still hiding outside, the lens catches a glimpse of a middle-aged woman, slowly turning on her feet - the only inhabitant of the house who seems to be awake at such an ungodly hour. The camera then cuts to the woman's hands and hovers over them as they swiftly turn over tortilla after tortilla on a scorching hot griddle. Again, the camera abruptly cuts to the other members of this sleepy household: it appears the woman is not alone. Now filling the tortillas with a nondescript mixture, the woman is left alone in the kitchen as the camera explores the tiny house. An older man is struggling with his wristwatch in one corner. In another, a young woman is getting dressed, while a second is still fast asleep on a bunkbed somewhere. Back in the kitchen, a young man is filling an ice box with ice cubes, as he and the now fully clothed woman tiptoe around a third sleeping girl, whose bed is placed in the middle of a room used as a kitchen, a bedroom, a dining room, and a living room all at once. With the car radio on full blast, the groggy group hops into a large van and starts driving into the sunrise. Even though the radio host can be heard reading the weather forecast in Mexican Spanish, the van appears to be driving on a US highway, following an all-American, green signpost that reads "County Line Road". On arrival, with traditional Mexican music still blaring in the background, the passengers descend, put on hats and gloves, swaddle their faces in colorful neckerchiefs, and walk out into miles and miles of grape vines, which they 
nimbly begin picking. Suddenly, everything turns dark. With the title "La Boda (The Wedding)" popping out of the black screen in white font, Weyer makes the surprise announcement that this film will be about something quite different from what has been shown so far. Or will it?

In the introductory sequence of Escuela (00:00:07-00:02:16), Weyer is more direct in evoking the bilingual and bicultural limbo that has become standard living for the Luis family. Sitting in an empty row at the back of a yellow, typically North American school bus, Lili drives by the camera, seemingly oblivious to her surroundings. In the meantime, her family is shown at home, frantically packing, folding, stacking all kinds of clothes, small furniture, lightweight items. The Luises are on the move - again. This time around, from the very beginning of the film, the cast is not only heard talking to themselves - in Spanish when it comes to the parents and in Spanglish or English when it comes to the children - but also to the camera. As in La boda, Weyer's audiovisual juxtapositions summon a sense of vacillation and equivocation. By having Lili's peaceful school bus scene clash with the family's hustle and bustle, Weyer seems to suggest that, despite their attempts at a sedentary lifestyle, the Luises are moored in a mental and physical no man's land whose territory is perpetually shifting. Their home has no anchor point. In the first few minutes of Escuela, reading between the lines of mother Juanita's short interaction with Weyer, it becomes clear she is very much aware of how her nomadic existence ties in with her migrant identity. As uncomfortable as it may be, migrancy is the Luises' baseline and their lifeline, but one they would happily swap for something more secure and stable. This unease with their hybridity - and the limitations it imposes on them - Juanita describes to the camera as follows, still tirelessly sorting through clothes:

Every year it's the same thing. Every year we have to pack our bags because I can't get work just anywhere here 
in Texas because I don't know English. I need to speak English for them to give me work. That's why I need to go to California to do field work. Over there, in the cotton fields, in the grapes... I have to work where I can. It's a compromise we have to make to live better. [...] I say to my kids - I want them to stick with school so they don't end up like me. If I had an education, I would stay right here. (00:00:44-00:01:31; original English subtitles).

In La boda, her daughter Elizabeth and her husband Eliazar make a similar allusion to how the family's migrant background forces them into permanent migration - a way of life that is so precarious and undesirable that it is usually associated with undocumented Mexicans, as Elizabeth implies (00:08:08-00:10:01). Put together, Elizabeth's irritation with people who assume she is not American, Eliazar's concern with making enough money to support his wife and children, and Juanita's lamentation about her lack of English proficiency testify of the Luises' unconscious incorporation of the age-old "one country, one language"-adage upon which the United States of America were built ( $c f$. Adams; Franklin).

According to Alejandro Portes and Richard Shauffler, this notion began gaining ground in the colonial and early independence period when, on the one hand, growing American nationalism popularized the idea that "American English both reflected and constituted the democratic and rational nature of the country" and, on the other, when the acquisition of English began to be seen as "the litmus test of citizenship" (642). In The Invention of Monolingualism, David Gramling further delves into the artificiality of monolingualism by pointing out its suspicious coincidence, worldwide, with the emergence of nations, national borders, and nationalism (Gramling). As Dennis Baron explains in his seminal book The English-only Question, the use and knowledge of English became an essential part of Americanism because it went hand in hand with the idea that a melting-pot nation like America could only truly come together and become one if a single language was used consistently

Cad. Trad., Florianópolis, v. 40, n $^{0}$ esp., p. 87-112, jan./jul. sem. 1. 2020.94 
throughout the land (Baron). That language had to be English, since "the ability to think logically, seen as necessary for democracy, was only possible on the basis of fluency in English" (Portes \& Schauffler 642). Slowly but surely, the American expectation of English-only monolingualism began seeping into classrooms. In the first half of the $20^{\text {th }}$ century, bilingualism was not only frowned upon, in the best cases, or banned entirely, in the worst, but in certain areas school children - those considered to be at risk of acquiring another mother tongue than English - were even made to take language loyalty oaths (Dillard). Starting from the sixties, however, a plethora of studies began disproving the folkloric assumption that bilingualism went hand in hand with intellectual failure by linking "true bilinguals" with enhanced cognitive abilities (e.g. Fernandez \& Nielsen). However, the USA were slow to recognize the benefits of multilingualism, mainly because of their tendency to equate monolingualism with democracy, national unity, and allegiance to the country - in schools and in public life (Portes \& Schauffler 642; $c f$. Dick; Gramling).

As Lieberson, Dalto, and Johnston remarked in the midseventies, America was quite unique in its linguistic intrusion in private homes: no other nation was so successful and consistent in eradicating mother tongues that were perceived to be non-native by the third generation. That, however, would soon change. Around the time of Eliazar and Juanita's marriage and cross-over to the United States, in the mid-sixties, the nature and the reception of incoming immigrants rapidly started altering, which would have a dramatic impact on the language skills and ethnic-racial identity of their offspring (Christophe et al.; Portes \& Zhou). The immigrants who began arriving from the sixties onwards were mostly nonEuropean, came from divergent socio-economic backgrounds, and settled in large enclaves, geographically concentrating in the West of the United States (Portes). Additionally, the economic conditions encountered by these new migrants were nothing like what their European predecessor had known. Because of America's emerging hourglass economy - in which opportunities for social mobility 
started shrinking, even among native-born Americans - and due to a welfare state that was increasingly contested by the general public, the adaption of these newcomers and their children became much more troublesome than that of previous arrivals (Zhou (a), 67). In that sense, the Luis family is a textbook example of this negative socio-economic phenomenon. Trying their best to adapt to a nation that abounds with subliminal messages relating the American dream to monolingual and monocultural integration, the family is very much aware of their failure to achieve "straight-line assimilation," which promises to "enable each succeeding generation to show upward social mobility in education and occupation" (Waters; et al.).

In their interviews with Weyer, the Luises explain that they learned the hard way that working in the fields does not pay off. As we learn in Escuela, Eliazar and Juanita were so worried they would not be able to make ends meet on two wages alone, that they felt they had no other choice than to pull their oldest children from school after $8^{\text {th }}$ grade.

The camera then turns to Lili, who announces that she is nervous and curious about entering $9^{\text {th }}$ grade (00:05:40-00:06:10). Her young enthusiasm is palpable and contagious: for a short while, the optimism that characterized a large part of La boda appears to sneak into Escuela. However, by interweaving Lili's teenage life with short segments of Elizabeth's adult worries post-La boda, Weyer subtly raises the question whether Liliana's future really will be all that better, now that she's been given the opportunity to finish high school. After all, her older sister Elizabeth did too but when her steady job at a bra factory in Mission, Texas falls through, she and her new husband - who is still trying to legalize his status $(00: 33: 15)$ - are forced to migrate yet again with her parents (00:42:50). It would seem that for these non-European immigrants, who already belonged to the lower socioeconomic classes of their sending country, and who end up settling in ethnic enclaves in the receiving country, education and English proficiency is no guarantee for upward mobility after all ( $c f$. Zhou \& Gonzales). 


\section{Adolescence and Assimilation}

From the 1960s on, the classical assimilation perspective upon which America's belief in the "one language, one culture"-axiom was based suddenly did not add up anymore. As Zhou explains:

In the literature on immigrant adaptation, the assimilation perspective has dominated much of the sociological thinking on the subject for the larger part of [the $20^{\text {th }}$ ] century. Central to this perspective are the assumptions that there is a natural process by which diverse ethnic groups come to share a common culture and to gain equal access to the opportunity structure of society; that this process consists of gradually deserting old cultural and behavioral patterns in favor of new ones; and that, once set in motion, this process moves inevitably and irreversibly toward assimilation. Classical assimilationists argue that migration leads to a situation of the "marginal man," in which immigrants are pulled in the direction of the host culture but drawn back by the culture of their origin (Park, 1928; Stonequist, 1937). This painful bipolar process, as Park sees it, entails a natural race relations cycle of contact, competition, accommodation (Park, 1928). Impacted by biotic forces (impersonal competition) and social forces (communication and cooperation), diverse immigrant groups from underprivileged backgrounds are expected to eventually abandon their old ways of life and completely "melt" into the mainstream through residential integration and occupational achievement in a sequence of succeeding generations. (Zhou (b), 976)

Curiously, the word choice and overall discourse used by the theoreticians mentioned here above is quite reminiscent of the kind of language that is often applied to refer to adolescence. Famously described by James Marcia as "identity synthesis" (Marcia, (a), (b)), adolescence is usually defined as the internal organization of certain drives, abilities, beliefs that are acquired by exploring 
a variety of options and committing to only a number of them (Bosma \& Kunnen; Schwartz et al.). Simplistically put, adulthood is psychologically perceived as the consistent reliance on a set number of drives, abilities and beliefs that remain after the elimination of a wide range of other choices during the transitional, experimental stage of adolescence - a phase during which certain behavioral and identitarian options (that are all hypothetically available during childhood) are considered, explored, and either discarded or maintained ( $c f$. Bogaerts et al.). Similarly, according to classical assimilationists, distinctive ethnic traits (e.g. culture, language, geographical concentration) are perceived as sources of disadvantage that have to be eliminated for the attainment of sane, fully-fledged assimilation (Child; Warner \& Srole; Wirth). Their straight-line assimilation theory anticipated that in the process of assimilating - which, in this context, almost appears synonymous to the process of reaching adulthood - most ethnic groups would lose all their distinctive characteristics and cease to exist as ethnic groups (Gordon). As Zhou explains, immigrants were expected to "free themselves from their old cultures in order to begin rising up from marginal positions" - a path similar to the coming-of-age process of adolescence (Zhou (b), 977).

Interestingly, Zhou notes an oppositional culture among young Americans, especially among those who have felt oppressed and excluded from the American mainstream and who have been frustrated by the widening gap between a culture that highly values freedom and materialism and the reality of a dwindling economic future (Zhou (a), 69). The Luis sisters can easily be classified as belonging to that demographic, going by their portrayal in Weyer's documentary tandem at least. Going against Gordon's prediction that every immigrant generation is destined to assimilate through, among other things, intermarriage with the majority population (Gordon), Elizabeth confirms in a dual interview with Artemio that she knew he was the one when he told her he was from Nuevo León, the Mexican home state of her parents. To him, however, origin did not matter: 
[Elizabeth] As soon as I found out he was from Chivo Leon, I was like, 'Sit down!'

[Artemio] I sat down and from that moment I didn't let go. I got to know her and we started to go out. And thanks to God...

[Elizabeth] But was it important for you...?

[Artemio] Yeah.

[Elizabeth] ...That we were both from Nuevo Leon?

[Artemio] No, not really. For me it'd be fine to meet a woman from another place as long as she understood me. (00:33:52-00:34:21; original English subtitles)

Their interaction confirms previous studies, in which European Americans are less likely to identify as American compared to their ethnic-minority peers. According to Rodriguez et al., they identify as White instead of identifying with a particular ethnic group and/or being American, because they see themselves as the norm (Rodriguez et al. 830). In a Mexican context, Artemio has probably never consciously given his ethnic-racial identity a second thought, therefore background and self-labeling matters much less to him than it does to Elizabeth, whose entire life is built around the ambiguity of who she is.

Her little sister Lili testifies in Escuela of the same need to construct a hyphenated identity that allows her to "maintain selfesteem" by valuing her Mexicanness "in resistance to the dominant majority white society" (Zhou (a), 69-70). Eating a hotdog in the back of a car, playfully joking around with her younger sister Yesenia and her cousin Janet, fourteen-year-old Lili declares that 
Mexican men "know how to treat a girl" - before concluding that all boys, White or Mexican, are "dogs" at least (00:11:47-00:13:46).

What in another instance could have passed for harmless teenage banter, becomes quite a grave matter in Weyer's film. Conscious of their less than desirable social standing in American society, tempted to what Zhou refers to as "acting white" (Zhou $(a), 69)$ by listening to English music, in Lili's case, or by playing with the idea of using birth control in Elizabeth's ( $\mathrm{Ca}$ boda 00:23:00), and vaguely aware of their inescapable marginality in a cultural context that equals Whiteness with Americanness ( $c f$. Devos \& Mohamed; West et al.) the Luis sisters refuse to accept the American "one language, one culture" ideal. They proudly proclaim their preference for Mexican love interests and insist on speaking Spanglish or Spanish with their Mexican-American friends and family. Their adolescence might be a matter of leaving unconstructive behaviors and beliefs behind, but their assimilation is not. The insidious parallel established by the "one culture, one language" credo between adolescence and assimilation does not hold up for Weyer's protagonists. They refuse to participate in an assimilation that is a "zero-sum experience in which one must lose one cultural identity to identify with another cultural group" (West et al. 965). Their individuation process is transformative and dynamic because it results "not only from the direct influences of each of their cultures but also from the processes they use to negotiate their cultures" (West et al. 967).

According to Portes and Zhou (1993) and Portes and Rumbaut (2001), the second generation of the post-1960s immigration wave - to which Lili and Elizabeth belong - tends to acculturate selectively. In less than favorable receptive circumstances, these newer immigrants hold on to their ethnic networks and identities in order to establish a certain amount of social capital and group solidarity in an otherwise quite hostile societal environment (Zhou (b)). This so-called segmented assimilation theory, coined by Portes and Zhou in their seminal paper "The New Second Generation: Segmented Assimilation and Its Variants" (1993), nuances the 
harshness of Perlmann and Waldinger's (1997) “second generation revolt" or Gans's (1992) "second generation decline" according to which the children of the newer wave of immigrants "will either not be asked, or will be reluctant, to work at immigrant wages and hours as their parents did but will lack job opportunities, skills and connections to do better" (Gans 173-174). The Luises, however, do not perceive their segmented assimilation as a failure. In $L a$ boda, Juanita explains their unity - be it within their family or within their ethnic Mexican enclaves in Texas and California - as a necessity and a welcome relief in the face of relentless adversity (00:50:34-00:51:38).

Aware that her family is far from attaining the ideal straightline assimilation so emphatically advertised in American society as a sine qua non, Juanita is nevertheless unrepentant. Within their means, they have achieved as much as they possibly could. Their receiving country might never fully accept them as one of theirs, but as long as the Luises can create and sustain a sense of belonging to each other, they will continue to feed off of that nurturing and self-sustained, albeit marginalizing, Mexican-American social capital to keep fighting for a better life - if not for themselves and their children, then for their grandchildren and their children.

\section{A Barbaric Conclusion}

Hannah Weyer's documentary tandem on the adolescence and assimilation of two Mexican-American migrant sisters is a timely portrayal of the struggle of an important portion of America's contemporary society: non-European immigrants who try to make a living in a country that has become all too willing to associate them with barbaric invaders ( $c f$. Nail). In La Boda and Escuela, Weyer gives the floor to two adolescent representatives of this barbaric, bilingual, bicultural tribe. Liliana and Elizabeth's reality - or the glimpses of their day-to-day that are supposed to give Weyer's audience a general (perhaps even a generalizing) idea of 
their reality - is one that does not strike with the invasion myth. However, Weyer turns the tables and plays with the victimperpetrator paradigm (Rothberg). With the help of evocative images, heartfelt interviews, and clever editing, she conveys a sense of awareness within the Luis family that America's political discourse, popular media, and even its legal - supposedly unbiased - bodies are particularly antagonistic towards Mexican immigrants and abound with analogies between them and their barbaric (racial, linguistic, geographic) inferiority (Nail 229). The Luises remain undeterred and undefeated, despite it all. Their family is their fortress and their assimilation into American society happens on their own terms, in their own time - not out of stubbornness, unwillingness or incapability but out of a pragmatism imposed on them by the dire socioeconomic circumstances of their reception.

Weyer never romanticizes the Luises hybrid existence, however. In that, she follows a growing trend within Latinx Studies that steps away from presenting liminality as a desirable state of mind and a celebratory expression of self-acceptance. Pablo Vila, for example, hammers on how stressful border existences can be and points out that this fact is entirely overlooked in the works of Gloria Anzaldúa or Guillermo Gómez-Peña (Vila) (2003). Angharad Valdivia admonishes that, far too often, hybridity is simplistically interpreted as a playful space, conveniently stripped of its marginalizing character and its terrifying capability to both deconstruct and reconstruct racism (Valdivia). Shane Moreman softens the Latinx concept of hybridity by appealing to Stuart Hall and Homi Bhabha's resignification process, which is "probably the best way to think through and out of oppressive meanings and their power constructs" (Moreman (b), 104).

Because of this need to resignify her liminal sense of self, in the final scenes of Escuela, Liliana recreates her hybrid, fractured, marginalizing identity on the outside by adjusting her appearance and donning goth outfits: 
[Liliana] Si Dios quiere, I'm gonna do my hair all blonde. Every single inch of my hair is gonna be blonde with red or black streaks. Or black hair, all my hair black, with blue or red streaks.

[Hannah Weyer] And why did you... How did you come up with the idea?

[Liliana] I came up with the idea coz I wanna become a civilized freak. They're giving like this big clue that I'm a freak, just because of my make-up and my skull but I don't care what they think. At least I know that I'm a smart, integ... intennigen... person! (00:41:04)

Who are "they"? Is Liliana truly referring to her high school peers? Or is she - consciously or unconsciously - provoking the world at large? A world that cornered her - and her family - into an awkward state of inbetweenness. A state she has to revendicate in order to not succumb to the shame that accompanies such marginalizing existence. That being said, Lili resists all clichés associated with Mexican youths and chooses for black clothes, dark make-up and a skull-necklace. Her look and her attitude are telling of her cynicism towards those who mock her, as well as of her unwillingness to be swallowed up by a bulldozing, homogenizing cultural matrix - be that high school, or American society. Elizabeth and Liliana are the epitome of Perlmann and Waldinger's (1997) "second generation revolt" rather than Gans's (1992) "second generation decline" in that their refusal to metaphorically drop their hyphen (Portes \& Schauffler 641) is more of an act of conscious defiance and resistance than it is the consequence of their supposed helplessness and defeat in a society that only applauds straight-line assimilation. 


\section{References}

Adams, J. The Works of John Adams, Second President of the United States: Life of John Adams. Boston: Little Brown and Company, 1856.

Anzaldúa, G. Borderlands - La Frontera: The New Mestiza. São Francisco: Aunt Lute Books, 1987.

Baron, D. E. The English-only Question: An Official Language for Americans? Yale: Yale University Press, 1990.

Berry, J. W. "Immigration, Acculturation, and Adaptation”. Applied Psychology. 46 (1), (1997): 5-34.

Berry, J. W.; Phinney, J. S.; Sam, D. L.; Vedder, P. “Immigrant Youth: Acculturation, Identity, and Adaptation”. Applied Psychology. 55 (3), (2006): 303-332.

Bhabha, H. K. The Location of Culture. Londres: Routledge, 1994.

Bogaerts, A., Claes, L.; Schwartz, S. J.; Becht, A. I.; Verschueren, M.; Gandhi, A.; Luyckx, K. "Identity Structure and Processes in Adolescence: Examining the Directionality of Between- and Within-Person Associations". Journal of Youth and Adolescence. 48 (5), (2019): 891-907.

Bosma, H. A.; Kunnen, E. S. "Determinants and Mechanisms in Ego Identity Development: A Review and Synthesis". Developmental Review. 21 (1), (2001): 39-66.

Buchanan, P. J. State of Emergency: The Third World Invasion and Conquest of America. New York: Thomas Dunne Books, 2006.

Caplan, N.; Choy, M. H.; Whitmore, J. K. "Indochinese Refugee Families and Academic Achievement”. Scientific American. 266 (2), (1992): 36-45.

Cad. Trad., Florianópolis, v. 40, n $^{0}$ esp., p. 87-112, jan./jul. sem. 1. 2020.104 
Child, I. L. Italian or American? The second generation in conflict. Yale: Yale University Press, 1943.

Christophe, N. K.; Supple, A. J.; Gonzalez, L. M. "Latent profiles of American and ethnic-racial identity in Latinx mothers and adolescents: Links to behavioral practices and cultural values". Journal of Latinx Psychology. (2019): s/p.

Coll, C. G.; Marks, A. K. (Eds.). "The immigrant paradox in children and adolescents: Is becoming American a developmental risk?". American Psychological Association. (2012): s/p.

Devos, T.; Mohamed, H. "Shades of American Identity: Implicit Relations between Ethnic and National Identities". Social and Personality Psychology Compass. 8 (12), (2014): 739-754.

Dick, H. P. "Language and Migration to the United States". Annual Review of Anthropology. 40 (1), (2011): 227-240.

Dillard, J. L. Toward a Social History of American English. Berlim: Walter de Gruyter GmbH \& Co KG, 2015.

Escuela | POV | PBS. (n.d.). POV | American Documentary Inc. Retrieved February 5, 2020, from http://archive.pov.org/escuela

Fernandez, R. M.; Nielsen, F. "Bilingualism and Hispanic scholastic achievement: Some baseline results”. Social Science Research. 15 (1), (1986): 43-70.

Fraga, L. R.; Segura, G. M. "Culture Clash? Contesting Notions of American Identity and the Effects of Latin American Immigration". Perspectives on Politics. 4 (2), (2006): 279-287.

Franklin, B. The Papers. Yale: Yale University Press, 1963.

Gans, H. J. "Second-generation decline: Scenarios for the economic and ethnic futures of the post-1965 American immigrants". Ethnic and Racial Studies. 15 (2), (1992): 173-192.

Cad. Trad., Florianópolis, v. 40, n $^{0}$ esp., p. 87-112, jan./jul. sem. 1. 2020.105 
Gómez-Peña, G. The new world border: Prophecies, poems, \& loqueras for the end of the century. São Francisco: City Lights Publishers, 1996.

Gordon, M. M. Assimilation in American life: The role of race, religion, and national origins. Oxford: Oxford University Press, 1964.

Gramling, D. The invention of monolingualism. New York: Bloomsbury Academic, 2018.

Haynes, J. From Huntington to Trump: Thirty Years of the Clash of Civilizations. Lanham: Rowman \& Littlefield, 2019.

Huntington, S. P. The Clash of Civilizations and the Remaking of World Order. New York: Simon \& Schuster, 1996.

Huntington, S. P (a). “The Hispanic Challenge”. Foreign Policy. 141, (2004): $30-45$.

Huntington, S. P (b). Who are We?: The Challenges to America's National Identity. New York: Simon and Schuster, 2004.

Lambert, W. E.; Tucker, G. R. Bilingual Education of Children: The St. Lambert Experiment. New York: Newbury House Publishers, 1972.

Lieberson, S.; Dalto, G.; Johnston, M. E. "The Course of Mother-Tongue Diversity in Nations". American Journal of Sociology. 81 (1), (1975): 34-61.

Marcia, James E(a). "Development and validation of ego-identity status". Journal of Personality and Social Psychology. 3 (5), (1966): 551-558.

Marcia, James E(b). "Identity in Childhood and Adolescence". International Encyclopedia of Social \& Behavioral Sciences. (2001): 7159-7163.

Markides, K. S.; Coreil, J. "The Health of Hispanics in the Southwestern United States: An Epidemiologic Paradox”. Public Health Reports (1974). 101 (3), (1986): 253-265.

Cad. Trad., Florianópolis, v. 40, $\mathbf{n}^{0}$ esp., p. 87-112, jan./jul. sem. 1. 2020.106 
Marks, A. K.; Ejesi, K.; Coll, C. G. "Understanding the U.S. Immigrant Paradox in Childhood and Adolescence". Child Development Perspectives. 8 (2), (2014): 59-64.

Moreman, S. T(a). Performativity and the Latina/o-whitehybrididentity: Performing the textual self. [PhD, University of South Florida]. 2005. Disponível em: http:// scholarcommons. usf. edu/cgi/viewcontent. cgi article $=3969 \&$ context $=$ etd. Acesso em: 12/12/2019.

Moreman, S. T(b). "Hybrid Performativity, South and North of the Border". Latina/o communication studies today, edited by A. N. Valdivia, Berna: Peter Lang, 2008, pp. 91-114.

Nail, T. The figure of the migrant. Stanford: Stanford University Press, 2015.

Park, R. E.; Burgess, E. W. The City. Chicago: University of Chicago, 1927.

Peal, E.; Lambert, W. E. "The Relation Of Bilingualism To Intelligence". Psychological Monographs: General and Applied. 76 (27), (1962): 1-23.

Perlmann, J.; Waldinger, R. "Second Generation Decline: Children of Immigrants, Past and Present: A Reconsideration”. International Migration Review. 31 (4), (1997): 893-922.

Portes, A. "Migration and Social Change: Some Conceptual Reflections". Journal of Ethnic and Migration Studies. 36 (10), (2010): 1537-1563.

Portes, A.; Rumbaut, R. G. Legacies the story of the immigrant second generation. California: University of California Press, 2001.

Portes, A.; Schauffler, R. "Language and the Second Generation: Bilingualism Yesterday and Today". International Migration Review. 4, (1994): 640-661.

Portes, A.; Zhou, M. "The New Second Generation: Segmented Assimilation and its Variants". The ANNALS of the American Academy of Political and Social Science. 530 (1), (1993): 74-96. 
Rodriguez, V. C.; Gillen-O’Neel, C.; Mistry, R. S.; Brown, C. S.; Chow, K. A.; White, E. S. "National and Racial-Ethnic Identification: What It Means to Be American Among Early Adolescents". The Journal of Early Adolescence. 36 (6), (2016): 807-839.

Rothberg, M. The Implicated Subject: Beyond Victims and Perpetrators. Stanford: Stanford University Press, 2019.

Rumbaut, R. G. "The Crucible within: Ethnic Identity, Self-Esteem, and Segmented Assimilation among Children of Immigrants". International Migration Review, 4, (1994): 748-794.

Schildkraut, D. J. "National Identity in the United States". Handbook of Identity Theory and Research, edited by Schwartz, Seth J., Koen Luyckx, and Vivian L. Vignoles, New York: Springer New York, 2011, p. 845-865.

Schwartz, S. J.; Zamboanga, B. L.; Luyckx, K.; Meca, A.; Ritchie, R. A. "Identity in Emerging Adulthood: Reviewing the Field and Looking Forward". Emerging Adulthood. 1 (2), (2013): 96-113.

Valdivia, A. N. "Latinas as Radical Hybrid: Transnationally gendered traces in mainstream media”. Global Media Journal. 3 (4), (2004). Disponível em: http://www.globalmediajournal.com/open-access/latinas-as-radical-hybridtrans nationally-gendered-traces-in-mainstream-media.php?aid $=35058$. Acesso em: 20/12/2019.

Vila, P. Ethnography at the border. Minnesota: University of Minnesota Press, 2003.

Warner, W. L.; Srole, L. The social systems of American ethnic groups. Yale: Yale University Press, 1945.

Waters, M. C.; Tran, V. C.; Kasinitz, P.; Mollenkopf, J. H. "Segmented assimilation revisited: Types of acculturation and socioeconomic mobility in young adulthood". Ethnic and Racial Studies. 33 (7), (2010): 1168-1193. 
West, A. L.; Zhang, R.; Yampolsky, M.; Sasaki, J. Y. "More Than the Sum of Its Parts: A Transformative Theory of Biculturalism". Journal of Cross-Cultural Psychology. 48 (7), (2017): 963-990.

Weyer, H. "La Boda". POV Season 13 (2000, June 27). PBS.

Weyer, H. “Escuela”. POV Season 15 (2002, August 27). PBS.

Wirth, L. "Culture Conflict and Delinquency. I. Culture Conflict and Misconduct". Social Forces. 9 (4), (1931):484-492.

Zhou, M.(a). "Growing Up American: The Challenge Confronting Immigrant Children and Children of Immigrants". Annual Review of Sociology. 23 (1), (1997): 63-95.

Zhou, M.(b). "Segmented assimilation: Issues, controversies, and recent research on the new second generation". The International Migration Review: IMR; Thousand Oaks. 31 (4), (1997): 975-1008.

Zhou, M.; Gonzales, R. G. "Divergent Destinies: Children of Immigrants Growing Up in the United States”. Annual Review of Sociology. 45 (1), (2019): 383-399.

Recebido em: 07/02/2020

Aceito em: 19/04/2020

Publicado em julho de 2020

Alexandra Jorgevna Sanchez. E-mail: alexandra.sanchez@kuleuven.be. ORCID: https://orcid.org/0000-0002-8999-8633

Cad. Trad., Florianópolis, v. 40, ${ }^{0}$ esp., p. 87-112, jan./jul. sem. 1. 2020.109 


\section{ANEXOS}

\section{LA BODA (THE WEDDING)}

A film by Hannah Weyer

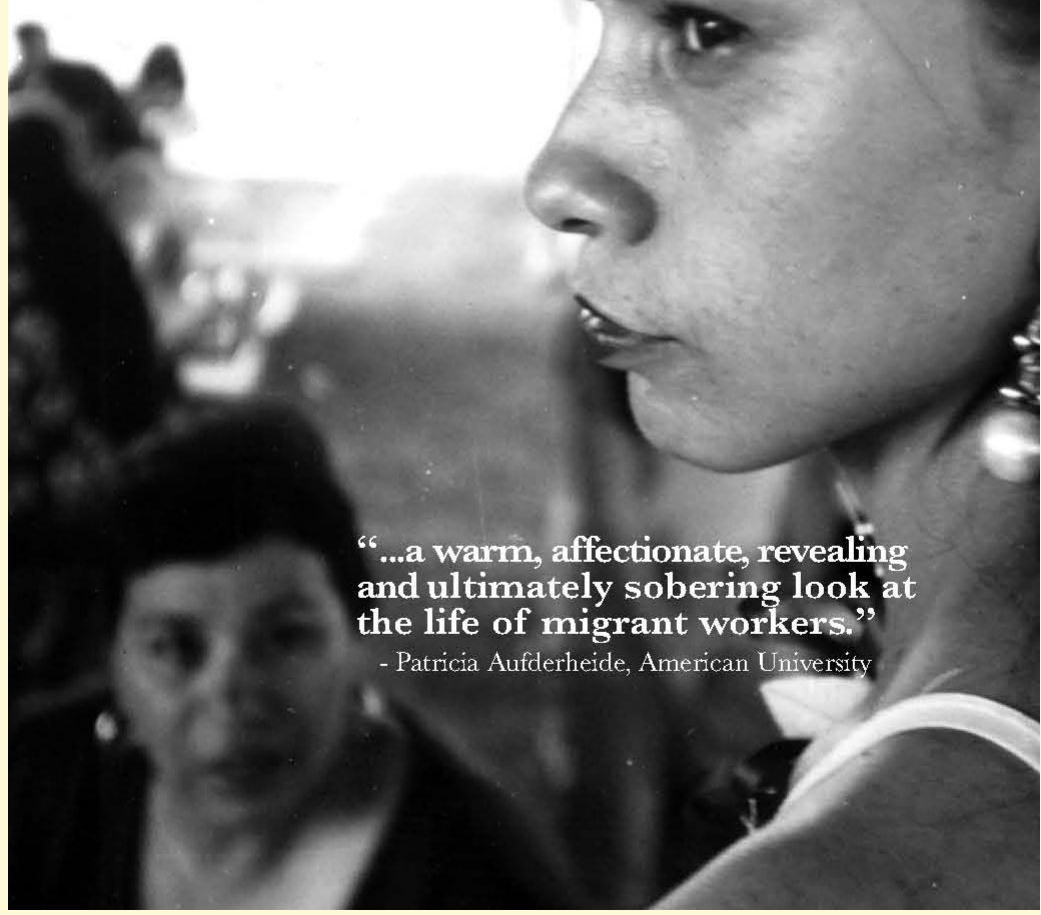

Cad. Trad., Florianópolis, v. 40, $\mathbf{n}^{0}$ esp., p. 87-112, jan./jul. sem. 1. 2020.110 


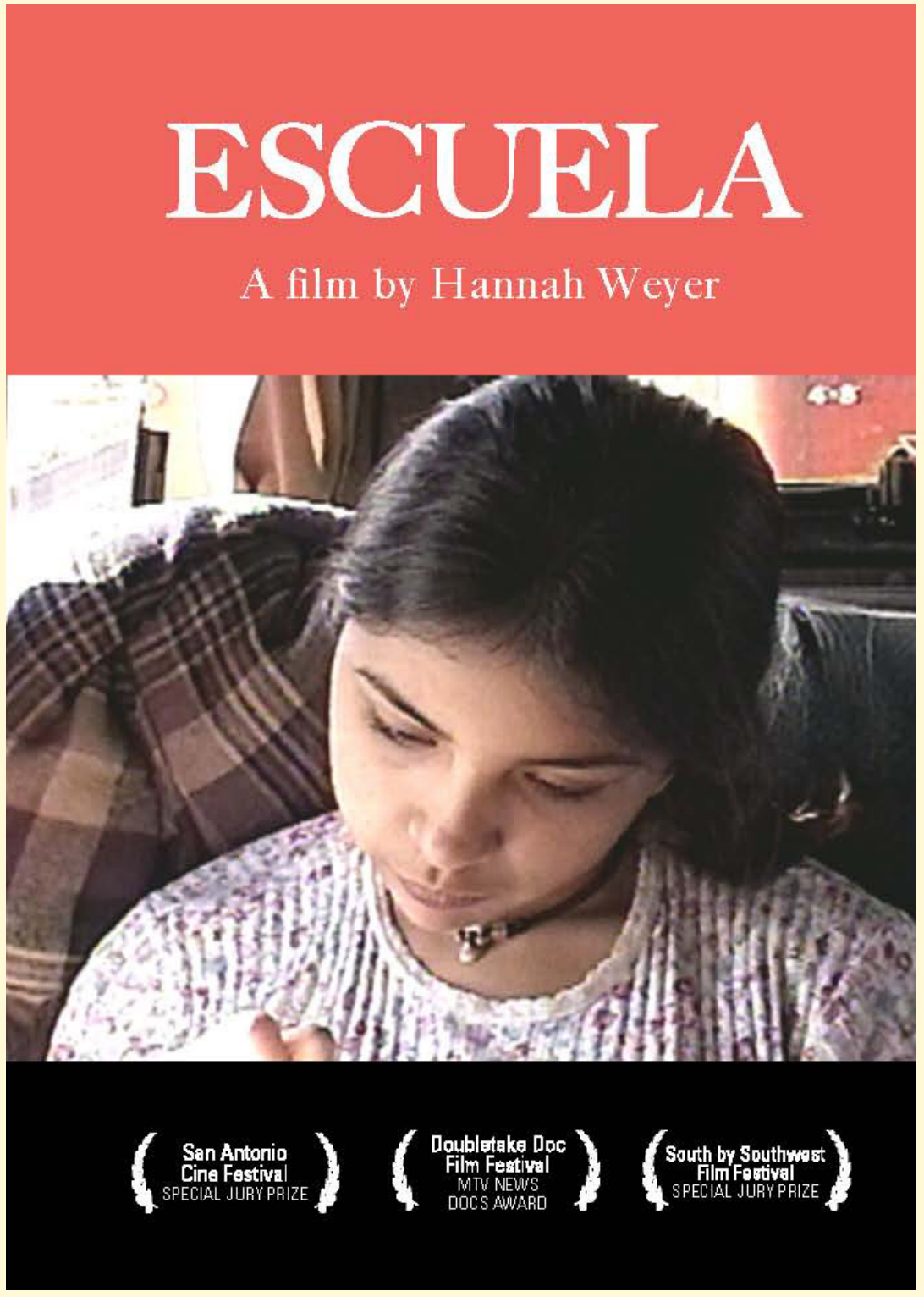

Cad. Trad., Florianópolis, v. 40, $\mathrm{n}^{0}$ esp., p. 87-112, jan./jul. sem. 1. 2020. 111 


\section{Information of the films:}

La Boda and La Escuela (distributed by Women Make Movies) aired on PBS as part of the POV-American Documentary series.

1. La Boda (The Wedding)

A film by Hannah Weyer

US, 2000, 53 minutes, Color, DVD,

English, Spanish Subtitles.

2. Escuela (School)

A documentary by Hannah Weyer

US, 2002, 53 minutes, Color, DVD,

Spanish/English, Subtitled 